\title{
Hidden Curriculum in Schools: A Comparison of Religious Otherness in Pakistani ELT Textbooks
}

\author{
Sajid Waqar ${ }^{1}$, Anita Bilal Burki ${ }^{2} \&$ Musarrat Jahan ${ }^{2}$ \\ ${ }^{1}$ Department of English, The Islamia University of Bahawalpur, Pakistan \\ ${ }^{2}$ Department of Education, The Islamia University of Bahawalpur, Pakistan \\ Correspondence: Sajid Waqar, Department of English, The Islamia University of Bahawalpur, Pakistan. E-mail: \\ sajidwaqar20@yahoo.com
}

$\begin{aligned} & \text { Received: September 22, } 2019 \\ & \text { Accepted: October 23, } 2019 \quad \text { Online Published: December 15, } 2019 \\ & \text { doi:10.5539/ijel.v10n1p194 }\end{aligned} \quad$ URL: https://doi.org/10.5539/ijel.v10n1p194

\begin{abstract}
The emphasis of this research was religious otherness depiction in high school English textbooks issued by four State controlled Pakistani textbook boards i.e., BTB Quetta, STB Jamshoro, KTB Peshawar and PTB Lahore. It besets a broad contrast among the religious otherness descriptions as depicted in provincial ELT textbooks and the otherness related notions of their corresponding students. To achieve the goals, the study was alienated in 2 phases: In phase 1, the textbooks of government textbook publishing boards were investigated and in the second phase their corresponding readers' religious otherness ideas were obtained and evaluated. The research devised a modified model of analysis by blending Van Dijk (1998) and Fairclough (2001) CDA model for interpretation and explanation of religious otherness in representative text extracted from textbooks' discourse. The study discovered the prevalence of religious otherness- related themes in all ELT textbooks. It was also found that STB discourse had improved religious otherness images and students' otherness ideas than other provincial textbook boards and their respective readers. The study also revealed that Muslim male and female students had peculiar otherness notions about minority religious communities. The readers' responses to questionnaire items in phase 2 of research suggested that textbooks had a significant part in molding otherness related notions of young readers. The study recommended an otherness-based investigation of the textbooks prior to publication at federal government level to ensure citizenship equality as envisioned by founder of the nation.
\end{abstract}

Keywords: ELT textbooks, religious otherness images, critical discourse analysis (CDA), students' religious otherness ideas

\section{Introduction}

The school is an important Ideological State Apparatus (Althuser, 1970). Any education system hinges on some curriculum and learning objectives. A hidden curriculum, according to Miller and Seller (1990), denotes unexpressed and implicit values, behaviors and norms in an education environment. According to Jerald (2006), the hidden curriculum is an implicit curriculum which expresses and signifies attitudes, knowledge, and behaviors, that are conveyed or communicated without aware intent; it is conveyed indirectly by words and actions that are parts of the life of everyone in a society. Cornbleth (1984) found that there are different elements that impact to shape the hidden curriculum, such as teachers, students, society, knowledge, and awareness. Moreover, knowledge of the hidden curriculum is of advantage to move towards a more enlightened future. As Myles (2011) noted that there is problem of the hidden curriculum that students may not recognize the rules of this type of curriculum. Therefore, students are put at disadvantage or embarrassing situations with their classmates in the classroom since they are not aware about the goal and rules of the hidden curriculum. Hidden curriculum is all the "unstated norms, values, and beliefs embedded in and transmitted to students through the underlying rules that structure the routines and social relationships in school and classroom life" (Giroux, 2001). The curriculum of an educational system is generally described explicitly for the purpose of simplicity of comprehension of all concerned especially the syllabus designers. However, certain invisible, embedded or implicit ideological themes/assumptions are also transmitted to the readership covertly. The nature of embedded themes or ideologies may vary from culture to culture.

Generally, the cultural themes like nationalism, racial discourses, language, ethnic diversity, geography, gender, otherness and religious beliefs/assumptions are found by the research works related to curriculum, syllabus and 
textbooks. This study has focused on only one form of hidden curriculum i.e., Otherness in textbooks. In modern times, De Beauvoir's (1949) introduced the notion of "the other" as a construction opposing and thereby constructing "the self". Since then the idea of "the other", "othering", and "otherness" has taken its roots to social and cultural areas (Crang, 1998). De Beauvoir's "other" was influenced if not entirely borrowed from Hegel's dialectic of identification and distantiation in his "Master-Slave Dialectic" (1807, B.IV.A). There are two dimensions of self and other described in "Master-Slave Dialectic": the political/historical and psychological dimension. The political dimension of self/other concerns the relationship between feudal lords and serfs. The psychological dimension is an abstract account of self-consciousness in relationship with the other. According to Crang (1998) othering is process through which identities are constructed in an unequal relationship. Othering reflects a superior self/in-group in contrast to an inferior other/out-group, but the superiority/inferiority is usually left implicit.

According to Staszak (2008), the tendency of a privileged, powerful or in-group to consider its members and values as superior to those of the less privileged or out-groups is termed as otherness. It is more related to the discourse rather than natural difference. Basically, it is the difference of power relation that is basis of otherness. Only the dominant and powerful groups construct the identity of otherness for the dominated or out-groups. For instance, if the other of man is woman and other of white man is black man its opposite is not true (Beauvoir, 1952; Fanon, 1963). The ability that imposes identities may be the combination of political, social, economic and discursive power. The western constructions of otherness prospered during the postcolonial era when the powerful West colonized and marginalized the colonized nations. However, it does not imply that the other societies do not practice otherness. With the emergence of various religions especially Christianity and Islam the self and other have also been created in certain societies on the basis of religion. The powerful rhetorical and discursive tools of dominance and subordination in the form of self and other, work well in the domain of mass media and textbooks. The general responses of othering may be segregation, secessionism, assimilation, inclusiveness and belongingness (Powell \& Menendian, 2016). However, the particular instances where othering has resulted in human genocide are; ethnic violence in Myanmar in 2012, racial in Nagorno-Karabakh in April 2016 and Turkish attack on Kurds of Syria and Iraq in 2015. In the perspective of this study the religious otherness can be elaborated as; Muslim self and non-Muslim other. In fact, the textbooks' contents related to religious otherness are pertaining to the political and religious situation of pre-partition India. The Muslims were in minority in United India before 1947 AD. Some Muslim thinkers were of expressed the idea that Hindus and Muslims of India were two distinct nations as their culture, customs and beliefs were divergent. This theory formed the basis of creation of Pakistan. Now the same pre-partition discourse of otherness may tend to marginalize the Hindu, Christian and other religious communities of Pakistan. The religion of Islam gives strong message of social equality and the founder of Pakistan Mr. Jinnah was also a staunch exponent of citizenship equality. The theme religious otherness in textbook's discourse has been dealt with in this perspective and context.

\subsection{Implication of the Research}

This study argues that the images of otherness are rooted in the form ideology of Pakistan and tend to marginalize the non-Muslim population of the country. The powerful Muslim readership is instilled through contents of syllabus with the ideas of superiority over non-Muslim citizens of the country and global non-Muslim community. Generally, the concepts like orientalism and ethnocentrism are associated with the Western superiority and Eastern inferiority basing on geography, race, language and ethnicity. However, this study is unique in a way that it contests Muslim superiority over non-Muslims as embodied in ELT textbooks. The aforementioned issues motivated the researchers to carry out this research. For this purpose, a modified analytical framework by combining Van Dijk (1998) and Fairclough (2001) was adopted to scrutinize the themes of otherness rooted in Pakistan's ELT textbooks. The research material comprised English textbooks prescribed for class 9 and 10 in government schools of the country. The study was not restricted to some specific geographical area rather it has incorporated all the provinces and federally controlled areas of the country. Moreover, countrywide the readership conceptions have also been obtained and quantified for the purpose of making the research adequately valid and sufficiently reliable. The research meant at bringing out rooted themes of religious otherness in the shape of hidden curriculum in school English textbooks of Pakistan. Another objective of the study was to record the notions of readers of textbooks with a view to measure the effects of hidden curriculum on the outlook and religious otherness related conceptions of the young student readers.

\subsection{Research Questions}

For accomplishing the research, the following questions were formulated: 
1) How religious otherness is signified in English textbooks of Pakistan?

2) How religious otherness in BTB, STB, KTB and PTB English syllabus differs from one another?

3) How religious otherness related contents influence the notions of corresponding young students?

\section{Theoretical Framework}

In recent past, the ELT textbooks have been targeted of research studies while focusing on aspects like racism, sexism, cultural representations, national identity, gender equality, culture and intercultural communicative competence and literacy practice. However, the main area of focus has been of identification of sexism and gender representations in ELT/EFL textbooks. Dabbahg and Noshadi (2016), Craeynest (2015), Hall (2014), Lee (2014), Lee and Collins (2008) have been generally carried out on firstness, omission, visibility linguistic biases in the selection of nouns and adjectives associated with each gender. These studies have found gender biases in textbooks and have recommended fair representation of female gender by the authors. Guijarro (2005), Yassine (2012), Aicega's (2007) have emphasized on the need to uncover the latent relationships between language, power, and ideology through the analysis of social problems such as the social classes, gender, minority communities, sexual orientation, religion, language, etc. Aicega's (2007) used the explicative and descriptive observation criteria and has been framed within Freire's (1993) and Giroux and Mc Laren's (1994) critical pedagogy, which has been characterized by questioning and rejecting all forms of domination, with the purpose of establishing a discourse for social action and transformation of reality. It has also been underpinned by Fairclough's (1989) critical discourse analysis, leading to the discovery of hidden relationships between language, power, and ideology.

Such studies on English textbooks have also been carried out in Pakistan. The major concentration has been on cultural, ideological and gender related themes in ELT textbooks. Very few studies have focused on themes of otherness in Pakistan's textbooks. The Islamic Republic of Pakistan has four provinces. All the provinces have their own textbook boards that design their respective syllabus while conforming to the national curriculum provided by the central government. The provincial Textbook Boards are; BTB Quetta, STB Jamshoro, KTB Peshawar and PTB Lahore. Pakistan emerged on political map of the globe in 1947 as a result of division of India in two parts by British Empire. The creation of Pakistan had two important and overlapping factors; ideology of Pakistan and 'Two Nation Theory'. It implied that the Muslims and Hindus of India were not one nation rather they were two distinct nations. The powerful social group in Muslim majority country of Pakistan (religious in this case) exercises its power through the discourse of textbooks.

Yaqoob (2011) was carried out to find cultural and gender images in secondary level textbooks of Punjab Textbook Board (PTB) and Cambridge Syllabus in Multan city of Pakistan. The study brought out that PTB textbooks did not emphasize much upon differences lying between the social and ethnic groups in Pakistan. The study did not include the ELT textbooks of other province; Baluchistan, Sindh and KPK.

Yassine (2012) evaluated the development of cultural contextualization in three Algerian EFL textbooks; Think it Over (1989), Comet (2001) and New Prospects (2007) and their conception(s) of the relation of the Self to the other. Looking at these textbooks as social discourses constructed in a multimode manner, it focused on key issues such as culture, ideology and otherness which were deemed very important for the construction of learners' conceptions where meaningful learning lead to the development of inter-cultural competence. It, therefore, explored which of the national/local, target/foreign, international/global. Other English-speaking countries or Western/European cultures were represented in the textbooks both at the linguistic level and at the visual level in an effort to capture the ideologies which under lied them.

Kello (2017) analyzed representation of the 'core Soviet era' (1945-1985) in Estonian post-Soviet history textbooks (1989-2016). Attitudes towards the Soviet system were a rich source for identity building, and hence a powerful political tool across the whole of the post-Soviet bloc. Based on an analysis of contents about the Soviet era in Estonia in textbooks, the study probed how textbooks represented wider processes of social meaning making, identity building and othering after a vital social and political turn. In 1989 and during the early 1990s, perspectives and narratives in Estonian history textbooks were deeply linked to social memory and national politics, enacting a specific social representation of the Soviet era that dominated the Estonian-speaking public space during the 1990s. The Soviet era, Russia and local Russians became the main others for Estonia and Estonians. However, the study found that the textbook and general public discourse though changed gradually in style yet maintained anti Soviet complexion.

Critical discourse analysis (CDA) is the unfolding of hidden ideologies embedded in the texts (Widdowson, 2000). It ascertains the central ideological bias and therefore the application of power in texts. In other words, 
critical discourse analysis and critical language education are concerned with the interests and ideologies underlying the construction and interpretation of textbooks. Blommaert (2005), in his argument of ideology, contends that power, especially institutionally produced power is central to CDA. The purpose of CDA is to analyze "opaque as well as transparent structural relationship of dominance, discrimination, power and control as manifested in language" (Wodak, 1995, p. 204). The power of dominant groups may be incorporated in laws, rules, norms, habits, and even a quite common consensus, and thus take the form of what Gramsci called hegemony (Gramsci, 1971). Fairclough's (2001) three-dimensional framework is one of major models utilized in discovering embedded themes in the ELT textbooks. In analyzing any communicative event, Critical linguistics deliberates three coinciding focuses: text, discourse practice and socio-cultural practice (Chouliaraki \& Fairclough, 1999). Fairclough (1989) assumes power, ideology and language as a unitary structure.

\section{Method}

This research is descriptive in nature, qualitative in approach with quantitative dimensions. The researchers used the qualitative research method of critical discourse analysis (CDA). This method uses an inductive research strategy, centering on the context, settings and perspective of the study rather than making generalizations from collected or representative data. The research paradigm of interpretivism was the major focus of this study. So, the researchers do not claim complete objectivity. For the pursuit of present study, all the regions of Pakistan were designated as research site.

\subsection{Study Material}

The material of the present study comprised of all matric level ELT textbooks followed in government schools of Pakistan. The detailed description of textbook titles is as under:

BTB

- “A TEXTBOOK OF ENGLISH Language Grade 9"

- "A Text Book of ENGLISH For Class X"

STB

- "SECONDARY STAGE ENGLISH BOOK ONE FOR CLASS IX"

- "Secondary Stage English Book Two For Class X"

KTB

- "Textbook of ENGLISH Grade - IX"

- "English Reading Book For Class 10"

PTB

- "ENGLiSH 9"

- "ENGLISH 10"

\subsection{Sampling}

The English textbooks of class 9 and class 10 published by provincial boards entitled BTB, STB, KTB and PTB. All the chapters and lessons of ELT textbooks were carefully read by the researchers. No text relating to religious otherness was left out from study. The repeated reading of the textbooks enabled the researchers to select the representative text (Appendix B to E), containing otherness related themes. The major objective of this study was to find out the predominant religious otherness-related themes in ELT textbooks. So, the rationale to select high school books were; the frequency of lessons written by Pakistani authors, significance of syllabus books in instilling the religious otherness notions in the thoughts of young male and female students and adequate ability and awareness of readers in comprehending of questionnaire contents, written in their second language (2L) i.e., English. 
Table 1. Areas where questionnaires were administered

\begin{tabular}{llll}
\hline Punjab Province/AJK \& GB & KPK Province & Baluchistan Province & Sindh Province \\
\hline Bhakhar & Abbottabad & Dera Bugti & Hyderabad \\
Kotli & Charsada & Qila Saifullah & Gotki \\
Lahore & Chitral & Quetta & Karachi \\
Lodhran & Hangu & Sui & Pano Aqil \\
Mandi Bahaudin & Karak & Zhob & Sukkar \\
Multan & Mansehra & & \\
Muzaffarabad & Peshawar & & \\
Skardu & & & \\
Vehari & & & \\
\hline
\end{tabular}

\subsection{Province Wise Detail of Respondents}

A total of fifteen hundred male and female students of 10th class were selected as research subjects of the questionnaire-based survey. However, it was endeavored to keep the number of respondents of different provinces in consonance with the actual population of respective provinces. The data have been compiled in percentage rather than number for easier comprehension and comparison. The Figure 1 below shows the details.

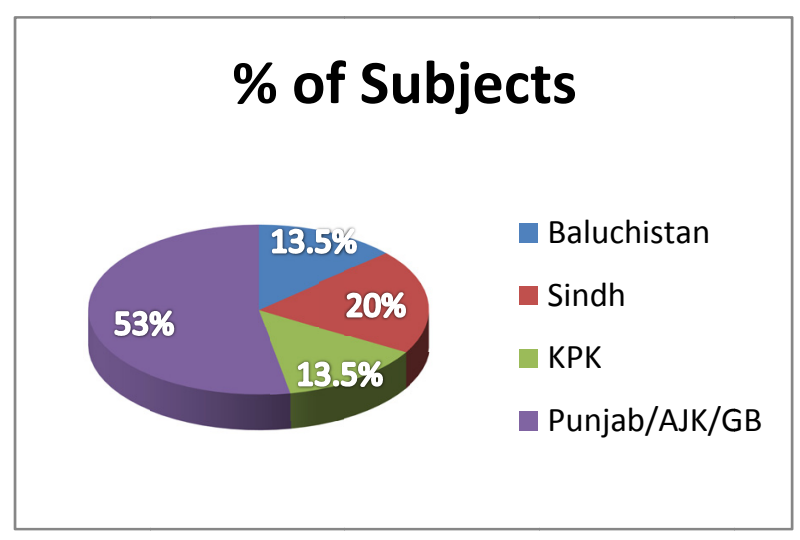

Figure 1. Province wise percentage of subjects

\subsection{Analytical Framework}

Van Dijk (1998), a prominent figure in CDA, contests that ideologies are socially common belief structures of groups and have social and mental denotations. The social function of ideologies is to identity, norms, values and text and talk for the purpose of legitimizing their dominance. Cognitively, the ideologies control the mental models and attitudes of different social groups. Van Dijk terms text as 'tip of the iceberg' where in the responsibility to deconstruct the hidden meaning lies with discourse analyst. For the purpose of bringing out hidden or embedded meaning it is advisable to carry out discourse analysis, social analysis and cognitive analysis of a piece of text simultaneously (Rahimi \& Sahragard, 2006). An important objective of CDA is to deconstruct the explicit and implicit ideologies in discourse that help produce and reproduce unequal power relations in the society (Fairclough \& Wodak, 1997). Van Dijk (2004) describes the discursive practice which mediate the ideologies as; metaphor, presupposition, difference, othering, foregrounding, back grounding, silence, modality, Implicature, prominence, polarization, lexicalization, hyperbole, evidentially etc.

The procedures for the analysis of otherness related themes were adopted from Yaqoob (2011) as discussed in theoretical framework section. Nevertheless, the substances of this research material directed the analysts in evolving the analytical groups and framework of analysis. The rooted themes in the representative qualitative data (Appendices B to E), taken out from English textbooks, were critiqued and analyzed by using a multimodal analytical framework provided by Van Dijk (1998) and Fairclough's (2001) model of critical discourse analysis (CDA) and. Fairclough (2001) contends that there are three stages of critical discourse analysis (CDA):

- Description: It encompasses the linguistic properties of the text under study.

- Interpretation: It involves the discursive practice of production and interpretation of text.

- Explanation: It describes the relationship between production and interpretation processes. 
Table 2. Analytical framework

\begin{tabular}{l}
\hline Provinces' ELT Textbooks \\
Pre Reading \\
\hline Representative Text \\
Critical Discourse Analysis (CDA) \\
Embedded Otherness Themes \\
\hline Readers' otherness notions
\end{tabular}

\subsection{Limitations of the Study}

The present study deconstructed the embedded religious otherness related themes in textbooks of government schools of Pakistan. Analytical framework was constructed by the researchers by combining the CDA model of Vandijk (1998) and Fairclough (2001). It was endeavored to keep the analysis objective by using the well tested analytical framework and guidelines provided in literature review. The researchers' definitely took a stand point of their own during qualitative analysis. So, the element of subjectivity cannot be repudiated. Moreover, this research relied on convenient sampling technique for the reason of heavy number of research subjects scattered in rural and urban area of a geographically large country with the population of over $200 \mathrm{~m}$. The generalizability of study results is not claimed by the researchers. Nevertheless, this research is distinctive as it has analyzed ELT syllabus of four different provincial textbook boards, functioning under the directions of national curriculum. So, the study has ventured a country wide project. The religious otherness-related notions of young rural and urban students were acquired questionnaire-based survey. Direct and elaborate questions were avoided due to the sensitivity of the issue and dictates of research ethics. The inferences drawn from responses on indirect questions might not be much valid and reliable due to cultural and social diversity of respondents of multi ethnic respondents. The opinion of various subject specialists and stake holders were not collected through individual interviews and focus group discussions due to dearth of resources and approachability.

\subsection{Delimitations}

This research has restricted application for analyzing English textbook syllabus being taught in government high schools of provincial and federal areas of Pakistan. The ELT syllabus of private education publishing companies has been left out due to restricted space of the study. The substances of only English subject syllabus have been investigated and other languages and social sciences subjects taught in state-run institutions have been excluded from the study. Likewise, only matric level English textbooks have been studied while leaving out ELT textbooks from grade 1 to 8 . In quantitative data the conceptions of readership have been collected through close-ended questionnaire. The open-ended questions have not been included due to difficulty of heavy qualitative data management.

\section{Results}

The theme of otherness has many relative connotations. Normally, in-groups and out-groups, center and periphery always struggle through their discourses to draw a social line against unprivileged factions of society. However, the present study focuses on the discourses produced by indigenous Pakistani writers. So, the 'self' relates to Muslims and 'other' to the followers of other religions like Hinduism and Christianity. Here, this theme will be deconstructed from ELT textbooks of all provincial textbook boards.

\subsection{Otherness in Baluchistan Textbook Board (BTB) ELT Textbooks}

The unit 1 of class X English textbook has the title "Unity, Faith and Discipline". The opening lines of the lesson have implied meaning of otherness. The opening sentence attributes the struggle for liberation and division of sub-continent to the unity of Muslims of India. The phrase "Muslims of sub-continent", presuppose all the Muslims of British India. The Muslims who did not demand a separate country for themselves have been back grounded in the discourse by the author. There were many Muslim leaders of freedom struggle who were in favor of free and united India. The historical fact has been back grounded in the discourse. There were even political parties led by Muslim leaders who were in favor of united India. According to the 3 June Partition Plan of 1947 the province of Punjab had to be split into East Punjab and West Punjab. The migration of population from one country to the other was neither planned nor envisaged by the British rulers and political leadership of Hindu dominant "All India Congress Party" and exclusively Muslim political forum "All India Muslim League". 
The shifting of population was the result of fear and chaos. In next sentence the modality of 'had to' is used in order to strengthen the argumentation. The abandoning of homes must be due to hard circumstances but was not forced by the state machinery. The phrase free country has been used as metaphor for Pakistan. In August 1947 both the countries i.e., Pakistan and India were liberated from British rule. However, the author implies that for the Muslims of sub-continent, Pakistan was the only country which ensured them freedom. A large majority of Muslim population residing in India were still in the captivity of Hindus as implied in the discourse of the lesson. The principles of unity, faith and discipline were propounded by Mr. Jinnah. He motivated the Muslims to follow these three principles in true letter and spirit. The three maxims were a source of hope for Muslims against the combined or united hostilities of British and Hindus. The lines written by the author represent Muslims as self and Hindus and British have been grouped as others. A future struggle has been pitched in the discourse between Muslims and non-Muslims.

\subsection{Otherness in Sindh Textbook Board (STB) ELT Textbooks}

In the context of Pakistan, the nationalism or patriotism is having some different dimensions which can be termed as Islamic or Muslim nationalism. Some Muslim leaders and scholars have propounded the idea of Muslim nation. They say that all the Muslims citizens living in different countries of the world are a distinct and one entity. This idea may be very attractive apparently but may not be simple enough for young readership to comprehend. King Faisal of Kingdom of Saudi Arabia (KSA) has been portrayed as united leader of Muslim Arab and Pakistan. In 1971 Pakistan was dismembered into two parts namely Bangladesh and Pakistan. King Faisal's unhappiness over the division has been depicted. India is Hindu majority neighboring country of Pakistan. It is a widely held belief that India played an instrumental role in creation of Bangladesh. So, King Faisal has been shown unhappy over the event. In next sentence, King Faisal has been described to be against the state of Israel. Here the Jews have been represented as others. Elder of the family, religious leader of the Muslims, Guardian of holy places and strengthened the Arabs in war against Israel are some phrases that have embedded message of Muslim unity against Israel. Here, Hindus and Jews have been portrayed as the enemies of Muslims. The Muslims of the world have been described as self and Jews and Hindus as others. The discourse of the lesson implies that the Muslims of the world were a united force under the leadership of King Faisal of Saudi Arabia. The Jews and Hindus were the enemies of the Muslims of the world.

The concluding paragraph of the unit titled, 'The Khyber Pass' has the images of otherness. The young school boys have been represented while on a tour of North Western region of Pakistan. The students have been represented to be fascinated by the invading soldiers of Central Asian Muslim warriors like Mahmood, Babur and Abdali. These conquerors invaded through the territory held by the tribesmen but the sentiments of the Muslim native people have been shown to be friendly with the invaders. The deep-rooted reason behind is that the Central Asian Muslim invaders attacked Hindu ruled areas of India. Here, the tribal Muslims have been identified with alien invaders from the north on the basis of common religion of Islam. Through the tool of polarization, Hindus and Muslims of United India have been represented with difference. The Hindus living in the same country with the Muslims have been shown as others. Before the partition of subcontinent a big community of Hindus inhabited the KPK province. No mutual interaction of Muslims and Hindus has been foregrounded. The discourse of the lesson is silent about the Hindu population living in present Pakistan area. Rather, there is a silence in discourse of the lesson about Hindu Muslim centuries' old interaction and common culture and customs. The theme of 'otherness is very much explicit in the description of tribesmen of the north west of Pakistan.

\subsection{Otherness in KPK-ELT Textbooks}

The representative text has been extracted from unit 2, class IX textbook, titled, 'Allama Muhammad Iqbal.' The theme of the unit has been reflected as 'role model' in the table of contents. The opening sentence of the extract carries the emotive tool of metaphor. The phrase "candle of freedom" has connotative meaning here. It means knowledge and guidance here. The light is needed when it is darkness all around. Darkness in the form of slavery of British and Hindus has been implied in the metaphoric phrase. The theme of religious otherness is also clearly reflected in the clause "Muslims and Hindus could not live together as one nation". In the discourse the strong modality of 'could' has been used discursively to make the argument strong. This modality stands for capability of performing some action. The author gives the message to readership that it was beyond the capability of Muslims of India to live in harmony with the Hindus. A renowned Muslim scholar and educationist of nineteenth century Sir Sayyed Ahmad Khan gave his famous 'two nation theory'. He was of the view that the Muslims and Hindus of India have different cultures, social norms and religious practices. He tried to convince the British rulers about separate identity of Muslims. Allama Muhammad Iqbal in his famous 'Allahabad Address of 1930' stressed the need of a separate country for Muslims living in north and western Muslim majority areas of India. 
But in the discourse of the lesson the phrase "Muslims must have an independent sovereign state of their own" has been used. The modality of must implies a strong need or binding. There is vagueness in the statement whether it implies that all the Muslims of subcontinent living in any part of India needed a sovereign state of their own or the Muslims living in Muslim majority areas needed an autonomous state. The theme of otherness is very explicitly embedded in the lesson.

The theme of otherness is again clearly visible in lesson number 3 titled 'Quaid-A Great Leader'. For the purpose of making the discourse emotive, the rhetorical tool of hyperbole of 'thousands' has been used by the writer. The strong phrase of 'attacked and killed' has been used for Hindus and Sikhs of India. Here, again the otherness theme is very much elaborated. The Hindus and Sikhs have been depicted as enemies of Muslims. The phrase entails that Muslims and non-Muslims of India are attackers and attacked and killers and killed respectively.

The theme of otherness is embedded in the paragraph about the description of wife of Mr. Liaquat Ali Khan. Begum Rana Liaquat Ali who was an activist of women's rights has been described as founding figure of medical related organization of nursing and first aid in Delhi. The medical field generally relates to all communities of a country. However, the opportunity has been depicted to be used for organization of only the Muslim women of India. The discourse of the lesson has resorted to silence on the ancestral religion of the lady. The population of India comprised Hindus, Sikhs, Christians, Muslims and many smaller religious communities. However, theme of otherness is used much visibly in the lines for non-Muslims of sub-continent.

Lesson number 9 of KPK English class X English textbook titled 'Muslims of China' is the description of the way of life of Muslim community of Peoples Republic of China. Me Chang the major character of the unit always identified himself with his fellow Muslims especially of Arab region. The fellow countrymen of Me Chang have been described as non-Muslims. So, Muslim nationalism or otherness is the prevalent theme of the unit. At present, the political and economic relations of Pakistan and China are very important for the countries of the region. Bow a day, the majority population of Peoples Republic of China is non-Muslim. However, positive exploitation of Muslims of China has been made by the author. On one hand, the sentiment of Pakistani and Chinese Muslims have been exploited and on the other hand, the Chinese Muslims have been identified with Muslims of the other regions particularly Saudi Arabia which enjoys the status of hub for the Muslims of entire globe. Saudi Arab is the place from where the great religion of Islam originated in sixth and seventh centuries $\mathrm{AD}$ and rapidly expanded on the globe.

\subsection{Otherness in Punjab Textbook Board (PTB) ELT Textbooks}

The lesson number 6, titled 'The Quaid's Vision and Pakistan' of PTB class IX English textbook contains themes of otherness. The lesson describes the personality of Mr. Muhammad Ali Jinnah. The major focus of the lesson is on political ideology of Mr. Jinnah. He has been described as staunch believer of Muslims as a distinct nation of British India. Many historians termed him as 'champion of Hindu Muslim unity' but this aspect has been back grounded in the discourse of PTB secondary English textbooks. It was after the Lahore Resolution of 1940 that the struggle for a separate country for Muslims of India got impetus. The political ideologies of Mr. Jinnah during last years of freedom movement have been foregrounded. The theme of otherness is implied and entailed in the lines of representative text (Appendix E).

\subsection{Qualitative Comparison of Religious Otherness in Provincial ELT Textbooks}

Here, the gist of religious otherness themes will be precisely presented for simplicity of comparison. The discourse of BTB textbooks bearing the theme of otherness hinges around freedom struggle of Muslims of India and atrocities of Hindus have been represented in order to foreground the theme of otherness. The Muslims of sub-continent have been represented as self and Hindus as others.

In STB discourse, the Muslims of the world have been represented as self and a single nation whereas the Jews have been represented as others. However, there is very minor trace of otherness attributed to Hindus.

The otherness related themes in KPK matric English textbooks mostly attribute self to the Muslims of subcontinent and otherness to Hindus. However, there is an indirect reference of global Muslim self in a lesson.

The PTB textbooks are most widely read ELT books in Pakistan because population - wise Punjab is the largest province of Pakistan. Moreover, schools under the federal government, Azad Jammu and Kashmir (AJK) and Gilgit Baltistan (GB) also follow PTB textbooks. The PTB textbooks express the theme of otherness very explicitly. The otherness has been ascribed to Hindus of sub-continent. 
Table 3. Units with otherness related themes in ELT textbooks

\begin{tabular}{ll}
\hline Publishing board & Units \\
\hline BTB & Faith, Unity, Discipline \\
STB & King Faisal, Khyber Pass \\
KTB & Allama Muhammad Iqbal, Quaid_-A Great Leader, Begum Rana Liaquat Ali, Muslims of China \\
PTB & The Quaid's Vision and Pakistan \\
\hline
\end{tabular}

\subsection{Otherness-Related Conceptions of Readership}

The part 2 of the research was about recording of readership conceptions. A comprehensive questionnaire was constructed for PhD study; however, the four items relating to religious otherness have been extracted for the purpose of brevity. The responses were obtained on five-point Likert scale. However, for the purpose of simplicity of comparison the responses of agree/strongly agree and disagree/strongly disagree have been collapsed in the Table 4.

Table 4. Otherness-related conceptions of readership

\begin{tabular}{lllll}
\hline Question statement & Corresponding Readers & Responses & & DK\% \\
\hline Pakistan should have good relations with Saudi Arabia. & & A $\%$ & DA\% & 9 \\
& BTB readers & 18 & 73 & 3 \\
& STB readers & 55 & 42 & 8 \\
Pakistan should have good relations with India. & KTB readers & 33 & 59 & 6 \\
& PTB readers & 51 & 43 & 11 \\
& BTB readers & 13 & 76 & 8 \\
We should help poor non- Muslim Pakistani people. & STB readers & 22 & 70 & 9 \\
& KTB readers & 6 & 85 & 3 \\
& PTB readers & 8 & 89 & 7 \\
Non- Muslim Pakistani citizens should have equal rights. & BTB readers & 70 & 23 & 2 \\
& STB readers & 76 & 22 & 11 \\
& KTB readers & 71 & 18 & 3 \\
& PTB readers & 70 & 27 & 5 \\
\hline
\end{tabular}

Note. Subjects: BTB readers-200, STB readers-300, KTB readers-200, PTB-800, Total-1500.

Legend: A = Agree, DK, Don't Know, DA = Disagree. Figures tabulated as \% age.

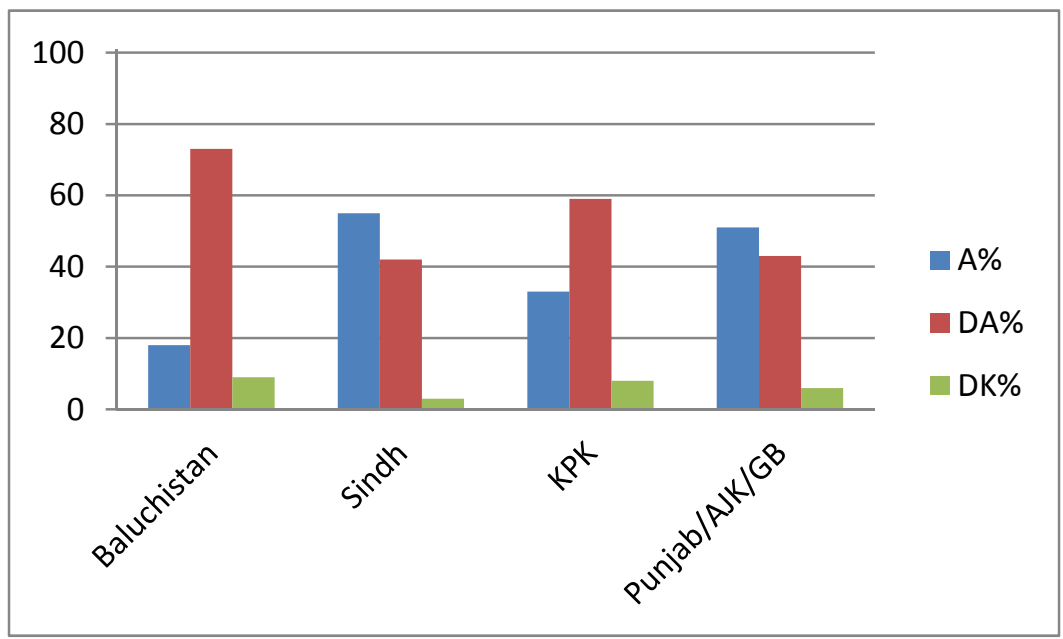

Figure 2. Pakistan should have good relations with Saudi Arabia 


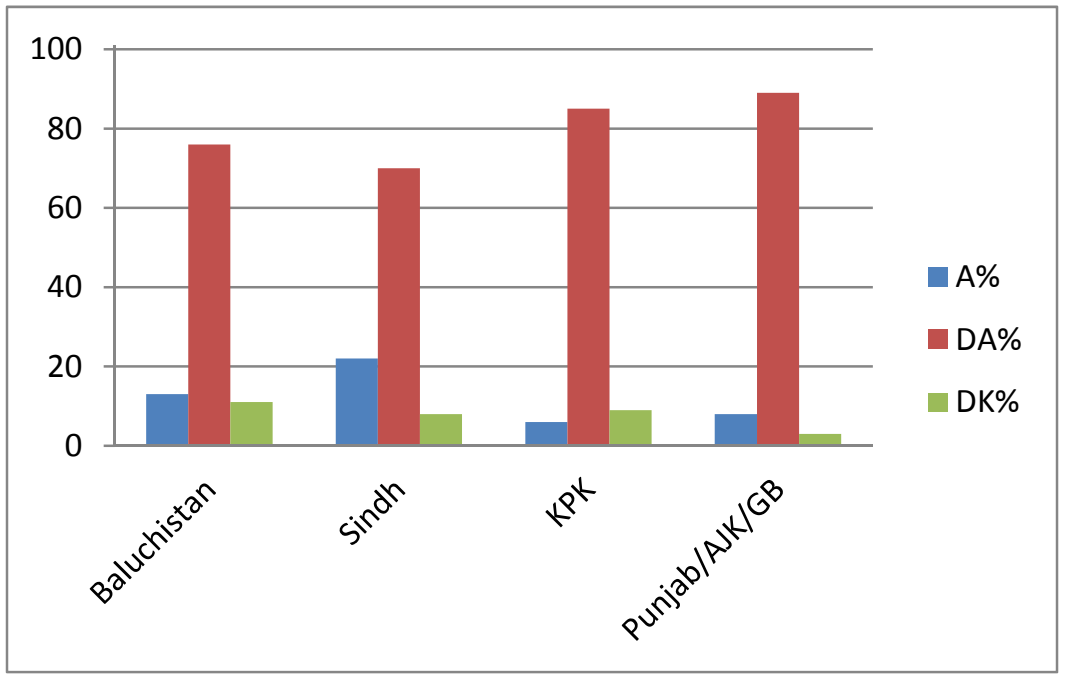

Figure 3. Pakistan should have good relations with India

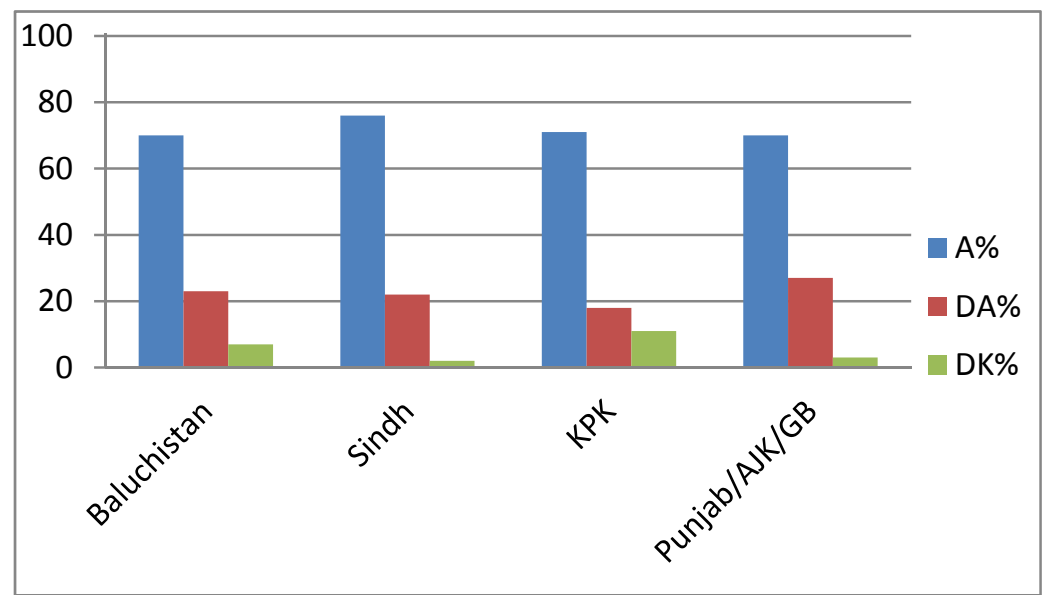

Figure 4. We should help poor non-Muslim Pakistani people

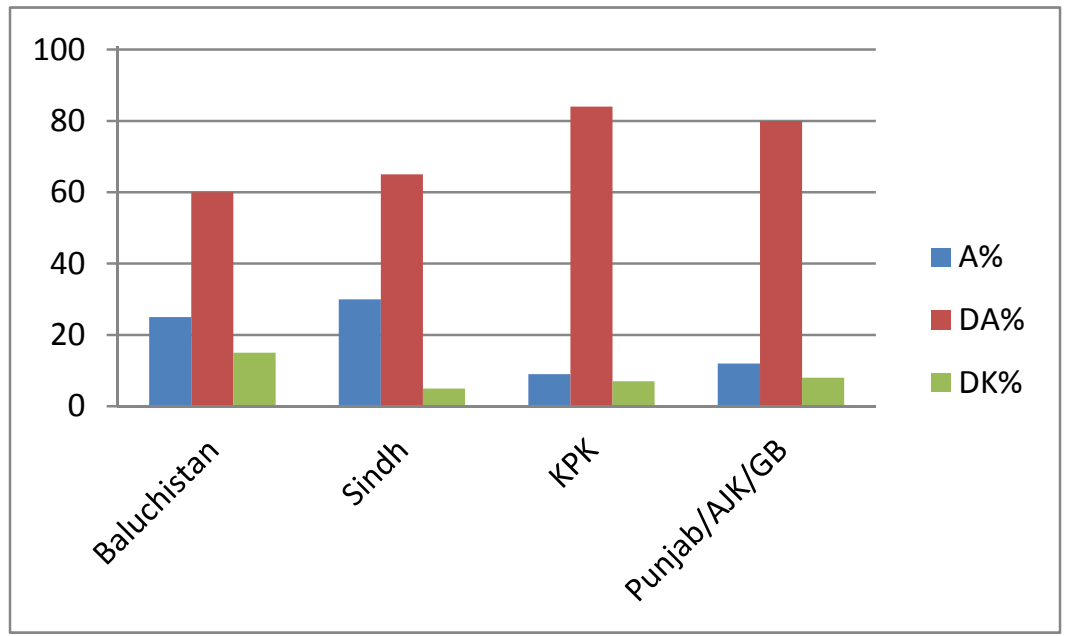

Figure 5. Non-Muslim Pakistani citizens should have equal rights 


\section{Discussion}

The religious otherness-related themes have been deconstructed and explored in the shape of hidden curriculum in High School level ELT textbooks of Pakistan. The otherness-oriented ideas of readership were acquired through survey-based questionnaire. There was significant alignment between textbook contents and young readers' otherness related conceptions. The qualitative comparison between textbook contents related to otherness of four state-run provincial publishing boards showed some variations in nature and orientation. Likewise, the degree or extent of effects of otherness themes on readership conceptions also varied from province to province and had adequate alignment with responding textbooks' contents. It implies that the ELT textbooks are very effective tools of transmitting various ideologies in readerships minds. The results of this study are reasonably aligned with the findings of Yaqoob (2011). For the purpose of exploration of religious otherness themes in Pakistani textbooks, English books of all the state-run provincial textbook boards were included in the study but the syllabus books of remaining subjects could not be incorporated due to limited scope of this research. Likewise, only matric level English syllabus textbooks were selected as sample of study. As far the deconstruction of embedded religious otherness themes is concerned, it is very natural for the researchers or analysts to take a stand point. The element of subjectivity cannot be eliminated in entirety. So, the researchers don't claim generalizability of results. Morse and Richards (2002) say that the researchers' quality is much prominently linked to results of qualitative research where basically the researcher who is himself/herself the research instrument. The first research question was pertaining to the way or mode of depiction of religious otherness in state sponsored provincial ELT textbooks. The study has revealed that the themes of Muslim self and Hindu and Jews others are there in almost all the government schools' ELT books. The research question 2 focused on the contrast of nature of religious otherness related themes in high school level provincial ELT textbooks. The research has found that the Sindh Textbook Board's discourse has negligible traces of 'Hindu' otherness but 'Jew otherness' related discourse is there in STB books. Remaining all the three textbook boards' ELT textbooks have Hindu other related themes in the historical context of Pakistan Movement. However, there are no traces of Christian otherness related themes in any of the textbook discourse. It is worth mentioning over here that there are people of many other religions living in Pakistan as citizens of state. The power of discourse may marginalize them. Especially, a good number of Hindus are living there in Baluchistan and Sindh provinces. Accordingly, STB textbooks' discourse seems much balanced regarding religious illustrations.

Just on creation of Pakistan, its founder Mr. Muhammad Ali Jinnah while making his inaugural address to the Constituent Assembly of Pakistan said "You may belong to any religion or caste or creed that has nothing to do with business of the State. We are starting in the days when there is no discrimination no distinction between one community and another. We are starting with the fundamental principle that we are all citizens and equal citizens one State....now I think we should keep that in front of us as our ideal and you will find that in course of time Hindus would cease to be Hindus, and Muslims would cease to be Muslims, not in the religious sense because that is personal faith of each individual, but in the political sense as the citizens of the State." (STB, IX, 60)

There is an explicit directive of equal citizenship rights given by the Constitutional Head of the State, to all the citizens, irrespective of their faith. The STB textbooks' discourse seems aligned with the vision given by the great Quaid. Probably, Mr. Jinnah could foresee the othering of minority communities in a State created on religious basis. He, very timely, advised the public and parliamentarian for equal citizenship rights to all.

The 3rd research question was regarding the religious otherness related conceptions of readership of ELT textbooks. It was very difficult to draft the valid contents of survey questionnaire and access the readership of four provinces. Moreover, the sensitivity of the matter socio cultural environments and research ethics limited the choice of direct and open questions. So, indirect questions were drafted to draw the inferences and conclusions. The validity of questionnaire was checked by a board of research experts. The quantified data (Table 4) about otherness conceptions of readership, obtained through close-ended questions, reasonably aligned and conformed to the respective textbooks' of young readership. The comparison of readership conceptions related to religious otherness indicated the STB readership had much moderate approach towards Hindu otherness. However, a good percentage of readerships of all the provinces showed allegiance with Saudi Arabia probably due to Muslim brotherhood. The process of randomization of data could not be followed during sampling of the questionnaire respondents. So, the convenient sampling could have affected the generalizability of quantitative data. Nonetheless, the rural and urban, male and female students were included in the study to maximize the validity of data. It is important to mention that social norms, cultural environments and religious atmosphere sufficiently affect the religious otherness related notions of young students. Moreover, in social sciences related studies the extraneous variables and factors cannot be easily eliminated or minimized. So, the 
effects on students' religious otherness related notions cannot be entirely ascribed to the textbook contents. Nonetheless, the study findings suggest that there is an adequate effect of textbooks' contents on readership conceptions. The results of this study are reasonably though not entirely in line with the outcomes of Yaqoob (2011).

\section{Conclusion}

This study targeted at investigating the type of religious otherness related discourse portrayed in the high school ELT textbooks distributed by Pakistan's four state-run provincial textbook boards. Additionally, one of its purposes was to match the types of religious otherness related depiction explicitly and implicitly embedded in four different prescribed ELT textbooks distributed by government sponsored provincial textbook boards and obtaining religious otherness related views of student readers of corresponding textbooks. The study was planned and executed in two phases i.e., textbook investigation and collection and investigation of readers' religious otherness related notions. The study relied on both the qualitative and quantitative research approach. The researchers devised and utilized a modified analytical framework by combining the CDA models provided Van Dijk (1998) and Fairclough (2001) for the purpose of deconstructing the religious otherness related themes in the representative text. The findings discovered that religious otherness related depiction of varying nature was there in four sets of textbooks. Nevertheless, on comparative basis the religious otherness depictions of STB were much better than those of KTB, BTB and PTB. In phase 2 of the study, the readerships' conceptions of corresponding ELT textbooks of high school of state-run institutions of the provinces were collected administering of questionnaire. The quantitative results of second phase of study found that Sindh Textbook Board (STB) readership had much accommodative and moderate views about non-Muslims in general and Hindus in particular. This is an important finding that supports the hypothesis of influence of textbook contents on young readers ideas and notions.

\section{Recommendations}

The depiction of all the religious communities as equal citizens of the State in textbooks' substances can contribute in making the students realize the involvement and value of smaller religious communities as a prolific and essential constituent of the society and State. A careful revision of all the published and prescribed Syllabus books in Pakistan should be carried out to guarantee the optimal depiction of citizens of State irrespective of their religion. The images of religious otherness in ELT provincial textbooks need ample transformation. Provincial government textbook boards should carry out the reappraisal of textbook substances for warranting religious and citizenship equivalence in the light of Quaid's vision.

\section{Acknowledgement}

This research paper titled "Hidden Curriculum in Schools: A Comparative Study of Religious Otherness in Pakistan's ELT Textbooks" has been partially extracted from the PhD Thesis titled "Ethics and Culture in Textbooks: A Comparative Study of ELT Syllabus of Pakistan's Provinces" which was conducted by Sajid Waqar under supervision of Prof. Dr. Mamuna Ghani Dean Faculty of Arts, The Islamia University of Bahawalpur, Pakistan and is being published in partial fulfillment of the requirements for the degree of $\mathrm{PhD}$ in Linguistics at The Islamia University of Bahawalpur, Pakistan.

\section{References}

Aicega, D. (2007). The English Textbook. Tensions from an Intercultural Perspective. Gist Education and Learning Research Journal, 17, 230-259. https://doi.org/10.26817/16925777.402

Beauvoir, S. D. (1952). The second sex. New York: Alfred Knopf.

Catherine, C. (1984). Beyond Hidden Curriculum? Journal of Curriculum Studies, 16(1), 29-36. https://doi.org/10.1080/0022027840160105

Chouliaraki, L., \& Fairclough, N. (1999). Rethinking Critical Discourse Analysis. Edinburgh: Edinburgh University Press.

Christopher, J. H. (1997). Morphology and Mind A unified approach to explanation in linguistics. Routeled Ge Liberary Editions: Linguistics.

Comet, O. N., Ziai, R., Hahn, M., \& Meurers, W. D. (2013). Comet: Integrating different levels of linguistic modeling for meaning assessment. Semeval@NAACL-HLT.

Crang, M. (1998). Cultural Geography. London: Routledge.

Dabbahg, A., \& Noshadi, M. (2016). Philosophy-based Language Teaching Approach on the Horizon: A 
Revolutionary Pathway to Put Applied ELT into Practice. Journal of Language Teaching and Research.

Fairclough, N. (1989). Language and Power. London: Longman.

Fairclough, N. (1992). Discourse and social change. Cambridge: Polity Press.

Fairclough, N. (1995). Critical Discourse Analysis: The critical study of language. London and New York: Longman.

Fanon, F. (1963). Black Skin, White Masks. Harmond sworth: Penguin.

Fowler, R. (1979a). Linguistics and the power. London: Methuen \& Cp. Ltd.

Fowler, R. et al. (1979b). Language and control. London: Routledge \& Kegan Paul.

Fowler, R. (1986). Linguistic criticism. Oxford/New York: Oxford University Press.

Fowler, R., Hodge, R., Kress, G., \& Trew, T. (1979). Language and control. London: Routledge and Kegan Paul.

Freire, P. (1971). Pedagogy of the oppressed. New York: Herder.

Giroux, H. A. (2001). Public spaces, private lives: beyond the culture of cynicism. New York; USA: Roman \& Littlefield.

Giroux, H., \& Mclaren, P. (Eds.). (1994). Between borders: Pedagogy and the politics of cultural studies. New York: Routledge.

Guijarro, J. R. (2005). Axiogical representation of gender and sexual orientation in the English textbook. Porta Linguarum, 4,151-166.

Hall, M. (2014). Gender representation in current EFL textbooks in Iranian secondary schools. Journal of Language Teaching and Research, 5(2), 253-261. https://doi.org/10.4304/j1tr.5.2.253-261

Hoare, H., \& Smith, G. N. (1971). Selections from the Prison Notebooks of Antonio Gramsci. New York, International Publishers.

Jan, B. (2005). Discourse: A Critical Introduction. Cambridge University Press. https://doi.org/10.1017/CBO9780511610295

Janice, M. M., \& Lyn, R. (2002). Readme First for a User's Guide to Qualitative Methods (p. 280). Thousand Oaks, London, New Delhi: Sage.

Jenner, B., \& Titscher, S. (2000). Methods of Text and Discourse Analysis.

Jerald, C. (2006). School Culture: The Hidden Curriculum. Issue Brief. Center for Comprehensive School Reform and Improvement.

Powell, J., \& Menendian, S. (2016). Segregation in the 21st Century. Poverty \& Race, 25(1). Poverty\& Race Research Action Council.

Katrin, K. (2017). Identity and Othering in Past and Present: Representations of the Soviet Era in Estonian Post-Soviet Textbooks. Journal of Social and Political Psychology, 5(2). https://doi.org/10.5964/jspp.v5i2.737

Kitchin, R., \& Thrift, N. (2008). International Encyclopedia of Human Geography. Elsevier.

Lee, J. F. (2014). A hidden curriculum in Japanese EFL textbooks: Gender representation. Linguistics and Education, 26, 39-53. https://doi.org/10.1016/j.linged.2014.07.002

Lee, J. F., \& Collins, P. (2008). Gender voices in Hong Kong English textbooks: Some past and current practices. Springer Science + Business Media, 59, 127-137. https://doi.org/10.1007/s11199-008-9414-6

Louis, A. (1970). Ideology and Ideological State Apparatuses. Lenin and Philosophy and Other Essays.

Miller, J. P., \& Seller, W. (1990). Curriculum: Perspectives and practice. Toronto: Coppclark Pitman.

Myles, F. (2011). Second language acquisition (SLA) research: its significance for learning and teaching issues. The LLAS Centre for Languages, Linguistics and Area Studies.

Rahimi, A., \& Sahragard, R. (2006). Critical Discourse Analysis: Euphemization and Derogation on the emails written on the death of the Pope.

Simone, D. B. (1949). The Second Sex. Vintage.

Van, C. (2015). Gender Representations in EFL Textbooks: A Quantitative and Qualitative Content Analysis, 
Universiteit Gent. Faculteitletteren en Wijsbegeerte. Vakgroep LW22.

Van Dijk, T. A. (1984). Prejudice in discourse: An analysis of ethnic prejudice in cognition and conversation. Amsterdam: John Benjamins Publishing Company. https://doi.org/10.1075/pb.v.3

Van Dijk, T. A. (1993). Principles of critical discourse analysis. Discourse and Society, 4, 249-283. https://doi.org/10.1177/0957926593004002006

Van Dijk, T. A. (1998). Ideology: A multidisciplinary approach. London: Sage Publications Ltd.

Van Dijk, T. A. (2001). Critical discourse analysis. In D. Schiffin, D. Tannen \& H. Hamilton (Eds.), The handbook of discourse analysis (pp. 1-43). Malden, Mass: Blackwell.

Verschuren, J., Ostman, J., \& Blommaert, J. (eds.). (1995). Handbook of Pragmatics: Manual (pp. 204-210). Amsterdam/Philadelphia: John Benjamins Publishing Company.

Widdowson, H. G. (2000). The Theory and Practice of Critical Discourse Analysis. Applied Linguistics, 19(1), 136-151. https://doi.org/10.1093/applin/19.1.136

Yaqoob, M. T. (2011). Ideology and worldview in textbooks: A study of cultural aspects in ELT in Pakistan. Doctoral dissertation, Bahaudin Zakariya University, Multan.

Yassine, S. (2012). Culture issues, ideology and otherness in EFL textbooks: A social, semiotic, multimodal approach. Unpublished Doctorate Thesis. Algeria: Mouloud Mammeri University of Tizi-Ouzou.

\section{Appendix A}

\section{List of Abbreviations}

\begin{tabular}{ll}
\hline AJK & Azad Jammu \& Kashmir \\
BTB & Baluchistan Textbook Board \\
CDA & Critical Discourse Analysis \\
ELT & English Language Teaching \\
GB & Gilgit Baltistan \\
KTB & Khyber Pakhtunkhwa Textbook Board \\
KPK & Khyber Pakhtunkhwa \\
OUP & Oxford University Press \\
PTB & Punjab Textbook Board \\
STB & Sindh Textbook Board \\
2L & Second Language \\
\hline
\end{tabular}

\section{Appendix B}

\section{BTB Representative Text}

"The Muslims of the subcontinent struggled hard for the creation of Pakistan. They had to sacrifice the lives of thousands of men, women and children. They had to abandon their homes, their jobs and their business behind in their march towards a free country. The inspiring leadership of Quaid-e-Azam Muhammad Ali Jinnah guided them out of countless difficulties. They displayed their strong belief in the principles of Unity, Faith and Discipline. These ideals kept their hopes alive against the combined hostilities of British and Hindus." (BTB, X, 3)

\section{Appendix C}

\section{STB Representative Text}

"King Faisal was a sincere friend and well-wisher of the people of Pakistan.

Perhaps no one outside Pakistan could be unhappy than King Faisal was, on the separation of East Pakistan which is now Bangladesh. He was against the State of Israel, because of its enmity towards the Arabs. He strengthened the Arabs in their war against Israel. He felt deeply grieved, when "Israelites set the Al-Aqsa Mosque on fire. He made every possible effort to get back the Arab territories under the illegal occupation of Israel...........The Muslims all over the world mourned his death. He lived like a soldier and died a martyr. With his death, not only Saudi Arabia but also the whole Muslim world has lost sincere and bold leader. He was the religious leader of the Muslims and the guardian of two holy places of the Makah-al-Mukarramah and Medina." (STB, X, 22) 
"As they stood looking at the hills, they thought of the brave soldiers of Mahmood, Babur and Abdali riding along this beautiful pass." (STB, X, 78)

\section{Appendix D}

\section{KTB Representative Text}

"Allama Iqbal awakened the Muslims of India and lit a candle of freedom in their hearts. He made them realize that Muslims and Hindus could not live together as one nation because they were two separate nations. Therefore, Muslims must have an independent sovereign state of their own. Iqbal for the first time proposed that Muslims should have a separate state of their own. Only then could Muslims hope to live free and honorable lives." (KPK, IX, 12)

"Perhaps he was thinking of the millions of people who had become homeless when India and Pakistan became separate countries. Perhaps he was thinking of the thousands who were being attacked and killed on the roads and railways as they tried to reach their homeland." (KPK, IX, 27)

"Her first opportunity to organize Muslim women presented itself in the same year, when she formed a small volunteer corps for nursing and first aid in Delhi." (KPK, IX, 54)

\section{Appendix E}

\section{PTB Representative Text}

"We are a nation, he affirmed three years before the birth of Pakistan, with our own distinctive culture and civilization, language and literature, art and architecture, names and nomenclature, sense of values and proportion, legal laws and moral codes, custom and calendar, history and tradition, aptitude and ambitions - in short, we have our own distinctive outlook on life." (PTB, IX, 63)

\section{Copyrights}

Copyright for this article is retained by the author, with first publication rights granted to the journal.

This is an open-access article distributed under the terms and conditions of the Creative Commons Attribution license (http://creativecommons.org/licenses/by/4.0/). 